\section{Total Syntheses of Ampelopsin D, Pallidol, and Quadrangularin A}

Synthesis of Natural

Products and

Potential Drugs

\section{Key words}

resveratrol

quadrangularin A

ampelopsin D

pallidol

decarboxylative

arylation

oxidative Heck

reaction

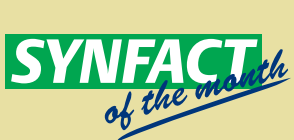

for $\mathbf{D}$ :<smiles>COc1ccc(/C=C2/c3cc(OC)cc(OC)c3C(c3ccc(OC)cc3)C2c2cc(OC)cc(OC)c2)cc1</smiles>

Quadrangularin A

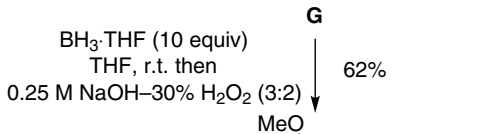

$$
\begin{aligned}
& \mathrm{Pd}(\mathrm{OAC})_{2}(5 \mathrm{~mol} \%) \\
& \mathrm{F}(4 \text { equiv) } \\
& \mathrm{TEMPO}(4 \text { equiv) } \\
& \mathrm{KF}(4 \text { equiv) } \\
& \mathrm{EtCO}_{2} \mathrm{H} \text {, r.t. } \\
& \hline 89 \% \\
& \text { oxidative Heck reaction }
\end{aligned}
$$<smiles>COc1ccc(CC2(C(=O)O)C=Cc3c(OC)cccc32)cc1</smiles>

$\left[\mathrm{Pd}(\mathrm{dba})_{2}\right](20 \mathrm{~mol} \%)$ BuONa (1.0 equiv) decarboxylative Arl (0.9 equiv) PMe, $110^{\circ} \mathrm{C}$ arylation
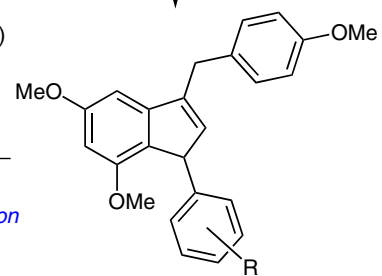

$\mathrm{D}: \mathrm{R}=4-\mathrm{OMe}(65 \%$ yield $)$ $\mathrm{E}: \mathrm{R}=3,5-(\mathrm{OMe})_{2}(57 \%$ yield $)$<smiles>Oc1ccc(C2C3c4cc(O)cc(O)c4C(c4ccc(O)cc4)C34C(c3ccc(O)cc3)c3c(O)cc(O)cc3C24)cc1</smiles><smiles>COc1ccc(C2c3c(OC)cc(OC)cc3C3(c4ccc(C)cc4)C(c4ccc(C)cc4)c4cc(OC)cc(OC)c4C23)cc1</smiles>

Heck reaction for $\mathrm{E}$ 1. $\mathrm{Pd}(\mathrm{OAc})_{2}(5 \mathrm{~mol} \%)$ H (4 equiv), I (4 equiv) $\mathrm{KF}$ (4 equiv), $\mathrm{EtCO}_{2} \mathrm{H}$, r.t.

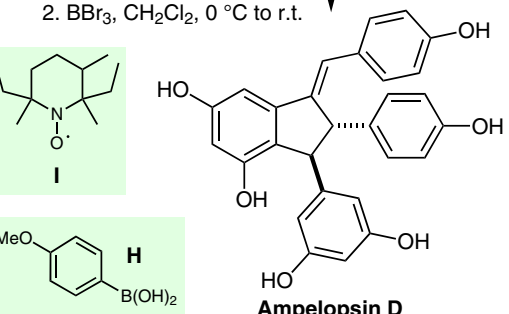

Significance: The polyphenols quadrangularin A ampelopsin $\mathrm{D}$ and pallidol consist of two resveratrol units. Considering the impressive biological activity of the monomer, these natural products are considered promising targets for further investigations. Klotter and Studer describe a highly modular approach that offers the possibility to introduce differently substituted aryl groups at will, allowing for the preparation of various analogues for biological investigations. The flexibility of the route is demonstrated by the short syntheses of racemic quadrangularin $A$, ampelopsin $D$ and pallidol.

SYNFACTS Contributors: Erick M. Carreira, Simon Breitler Synfacts 2014, 10(5), 0447 Published online: 17.04.2014 DOl: 10.1055/s-0033-1341094; Reg-No.: C01514SF
Comment: The approach is centered on two consecutive palladium-catalyzed coupling reactions. Decarboxylative arylation of indene carboxylic acid $\mathbf{C}$, accessible in eight steps from cinnamic acid derivative $\mathbf{A}$, gave indenes $\mathbf{D}$ and $\mathbf{E}$ depending on the aryl iodide employed. Oxidative Heck reactions with aryl boronic acids $\mathbf{F}$ or $\mathbf{H}$ afforded, after deprotection, quadrangularin A and ampelop$\sin D$ from $\mathbf{D}$ and $\mathbf{E}$, respectively. Hydroboration, oxidation, and deprotection of intermediate $\mathbf{G}$ allowed for the preparation of pallidol. 